\section{Parliament in Britain}

\section{University Grants}

In the House of Lords, Baroness Phillips, answering for the Government on university expenditure and government grants, said Parliament had voted $£ 22.5$ million for 1967-68 for the purpose of meeting drawings on university furniture and cquipment. The UGC, when issuing the initial drawing limits, decided to work within a total of $£ 20$ million, keeping $£ 2.5$ million in reserve. Universities were invited to submit a claim if they wanted a higher limit, and in the event the claims amounted to $£ 21.5$ million over and above the total of the limits notified earlier. The UGC saw no possibility of justifying this increase and had pro-

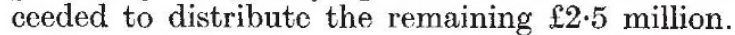

She said that it was certainly true that the limit which had been assigned to some universities might prove to be less than they could legitimately claim that they nocded and less than they would have drawn if the drawing of grants had been left to take their course as in the past. But it was also true overall that more money was being provided for furniture and equipment than in any year in the past. The UGC was making a careful study of the situation, and particularly that of the comparatively small number of universities where, because of particular circumstances, the impact of drawing units had been particu. larly hard. (Debate, July 25.)

\section{Co-operation}

IN a debate on Science and Technology (Anglo-European Co-operation), Mr Eric Moonman, M.P. for Billericay, said that for many years science and technology had failcd to make the impact in Western Europe which might have been expected. People holding key positions in government and industry had. failed to pay science and technology due attention. Decisions had been taken about short- and long-term planning without reference to those sections of Government that were encouraging scientific projects, while in industry large numbers of companies in Europe felt it undesirable or unnecessary to appoint scientists or technologists to key positions or on boards of executives. As a result, their voice was not heard or was not loud enough. Collaboration among European nations and firms was important, he thought, but needed to be established on a meaningful basis.

Mr Anthony Wedgwood Benn., Minister of Technology, agreed with almost all $\mathrm{Mr}$ Moonman had said. The high cost of research made it necessary to establish companies large enough to afford it, and the high cost of marketing made it necessary to have large markets to sustain this research. Britain was handicapped by the fragmentation of firms. Although some of Britain's corporations were of a world size they were opcrating on too small a scale. It was one of the principal objects of the Ministry of Technology to try to bring about larger units in the British engineering industry. (Debate, July 24.)

\section{Booms}

IN a written answer, Mr Anthony Wedgwood Benn, Minister of Technology, said that the sonic boom heard in the London area on July 17 was not comparable in noise, effect or decibel measurement to that which could be expected from Concord. (Written answer, July 21.)

\section{Doctors}

IN a written reply, $\mathrm{Mr} \mathbf{K}$. Robinson, the Minister of Health, said that an interview team of five, headed by the Principal Medical Officer from his department, was being sent to visit the USA and Canada early in the autumn to meet British doctors there and offer them appointments in the hospital service or introductions to general practice or to hospital boards. The project had been publicized in the medical press and a large number of inquiries had already been received from British doctors interested in returning to Britain. (Written answer, July 24.)

\title{
Keeping an Eye on Universities
}

\begin{abstract}
Universities in Britain are soon to have another intermediary in their increasingly uneasy relationship with the Government. From the beginning of next year the financial affairs of the universities will be open to audit by the Comptroller and Auditor General, the Government financial watchdog. Most of the universities are unenthusiastic about the idea, but need more details of how the scrutiny will operate before committing themselves.
\end{abstract}

by our Special Correspondent
(Nature, 213, 438; 1967). In addition, it may be that universities, traditionally slow to react, are still embroilod in arguments with the University Grants Committee about equipment grants.

The Public Accounts Committee announced its recom. mendations in January this year. Thoy were short and to the point; from August 1, 1967, the comptroller should be given access to the books and records of the UGC and the universities, and in the meantime stops should be taken both to work out suitable conventions as to how the scrutiny should bo handled and to ensure that 